University of Louisville

ThinkIR: The University of Louisville's Institutional Repository

Faculty Scholarship

4-1987

From silence to words : writing as struggle.

Min-Zhan Lu

University of Louisville

Follow this and additional works at: https://ir.library.louisville.edu/faculty

Part of the English Language and Literature Commons, and the Rhetoric and Composition Commons

Original Publication Information

Lu, Min-Zhan. "From Silence to Words: Writing as Struggle." 1987. College English 49(4): 437-448.

This Article is brought to you for free and open access by ThinkIR: The University of Louisville's Institutional Repository. It has been accepted for inclusion in Faculty Scholarship by an authorized administrator of ThinkIR: The University of Louisville's Institutional Repository. For more information, please contact thinkir@louisville.edu. 


\section{From Silence to Words: Writing as Struggle}

Imagine that you enter a parlor. You come late. When you arrive, others have long preceded you, and they are engaged in a heated discussion. . . . You listen for a while, until you decide that you have caught the tenor of the argument; then you put in your oar. Someone answers; you answer him; another comes to your defense; another aligns himself against you, to either the embarrassment or gratification of your opponent, depending upon the quality of your ally's assistance. However, the discussion is interminable. The hour grows late, you must depart. And you do depart, with the discussion still vigorously in progress.

-Kenneth Burke, The Philosophy of Literary Form

Men are not built in silence, but in word, in work, in action-reflection. -Paulo Freire, Pedagogy of the Oppressed

My mother withdrew into silence two months before she died. A few nights before she fell silent, she told me she regretted the way she had raised me and my sisters. I knew she was referring to the way we had been brought up in the midst of two conflicting worlds-the world of home, dominated by the ideology of the Western humanistic tradition, and the world of a society dominated by Mao Tsetung's Marxism. My mother had devoted her life to our education, an education she knew had made us suffer political persecution during the Cultural Revolution. I wanted to find a way to convince her that, in spite of the persecution, I had benefited from the education she had worked so hard to give me. But I was silent. My understanding of my education was so dominated by memories of confusion and frustration that I was unable to reflect on what I could have gained from it.

This paper is my attempt to fill up that silence with words, words I didn't have then, words that I have since come to by reflecting on my earlier experience as a student in China and on my recent experience as a composition teacher in the United States. For in spite of the frustration and confusion I experienced growing up caught between two conflicting worlds, the conflict ultimately helped me to grow as a reader and writer. Constantly having to switch back and

Min-zhan Lu teaches in the English Department at the University of Pittsburgh, where she is completing a dissertation on literary practice in Chicago in the 1890s in the Cultural and Critical Studies Program. She has also done graduate work in the University of Pittsburgh's Composition Program.

\section{College English, Volume 49, Number 4, April 1987}


forth between the discourse of home and that of school made me sensitive and self-conscious about the struggle I experienced every time I tried to read, write, or think in either discourse. Eventually, it led me to search for constructive uses for such struggle.

From early childhood, I had identified the differences between home and the outside world by the different languages I used in each. My parents had wanted my sisters and me to get the best education they could conceive of-Cambridge. They had hired a live-in tutor, a Scot, to make us bilingual. I learned to speak English with my parents, my tutor, and my sisters. I was allowed to speak Shanghai dialect only with the servants. When I was four (the year after the Communist Revolution of 1949), my parents sent me to a local private school where I learned to speak, read, and write in a new language-Standard Chinese, the official written language of New China.

In those days I moved from home to school, from English to Standard Chinese to Shanghai dialect, with no apparent friction. I spoke each language with those who spoke the language. All seemed quite "natural"- -servants spoke only Shanghai dialect because they were servants; teachers spoke Standard Chinese because they were teachers; languages had different words because they were different languages. I thought of English as my family language, comparable to the many strange dialects I didn't speak but had often heard some of my classmates speak with their families. While I was happy to have a special family language, until second grade I didn't feel that my family language was any different than some of my classmates' family dialects.

My second grade homeroom teacher was a young graduate from a missionary school. When she found out I spoke English, she began to practice her English on me. One day she used English when asking me to run an errand for her. As I turned to close the door behind me, I noticed the puzzled faces of my classmates. I had the same sensation I had often experienced when some stranger in a crowd would turn on hearing me speak English. I was more intensely pleased on this occasion, however, because suddenly I felt that my family language had been singled out from the family languages of my classmates. Since we were not allowed to speak any dialect other than Standard Chinese in the classroom, having my teacher speak English to me in class made English an official language of the classroom. I began to take pride in my ability to speak it.

This incident confirmed in my mind what my parents had always told me about the importance of English to one's life. Time and again they had told me of how my paternal grandfather, who was well versed in classic Chinese, kept losing good-paying jobs because he couldn't speak English. My grandmother reminisced constantly about how she had slaved and saved to send my father to a first-rate missionary school. And we were made to understand that it was my father's fluent Engiish that had opened the door to his success. Even though my family had always stressed the importance of English for my future, I used to complain bitterly about the extra English lessons we had to take after school. It was only after my homeroom teacher had "sanctified" English that I began to connect English with my education. I became a much more eager student in my tutorials. 
What I learned from my tutorials seemed to enhance and reinforce what I was learning in my classroom. In those days each word had one meaning. One day I would be making a sentence at school: "The national flag of China is red." The next day I would recite at home, "My love is like a red, red rose." There seemed to be an agreement between the Chinese "red" and the English "red," and both corresponded to the patch of color printed next to the word. "Love" was my love for my mother at home and my love for my "motherland" at school; both "loves" meant how I felt about my mother. Having two loads of homework forced me to develop a quick memory for words and a sensitivity to form and style. What I learned in one language carried over to the other. I made sentences such as, "I saw a red, red rose among the green leaves," with both the English lyric and the classic Chinese lyric-red flower among green leavesrunning through my mind, and I was praised by both teacher and tutor for being a good student.

Although my elementary schooling took place during the fifties, I was almost oblivious to the great political and social changes happening around me. Years later, I read in my history and political philosophy textbooks that the fifties were a time when "China was making a transition from a semi-feudal, semi-capitalist, and semi-colonial country into a socialist country," a period in which "the Proletarians were breaking into the educational territory dominated by Bourgeois Intellectuals." While people all over the country were being officially classified into Proletarians, Petty-bourgeois, National-bourgeois, Poor-peasants, and Intellectuals, and were trying to adjust to their new social identities, my parents were allowed to continue the upper middle-class life they had established before the 1949 Revolution because of my father's affiliation with British firms. I had always felt that my family was different from the families of my classmates, but I didn't perceive society's view of my family until the summer vacation before I entered high school.

First, my aunt was caught by her colleagues talking to her husband over the phone in English. Because of it, she was criticized and almost labeled a Rightist. (This was the year of the Anti-Rightist movement, a movement in which the Intellectuals became the target of the "socialist class-struggle.") I had heard others telling my mother that she was foolish to teach us English when Russian had replaced English as the "official" foreign language. I had also learned at school that the American and British Imperialists were the arch-enemies of New China. Yet I had made no connection between the arch-enemies and the English our family spoke. What happened to my aunt forced the connection on me. I began to see my parents' choice of a family language as an anti-Revolutionary act and was alarmed that I had participated in such an act. From then on, I took care not to use English outside home and to conceal my knowledge of English from my new classmates.

Certain words began to play important roles in my new life at the junior high. On the first day of school, we were handed forms to fill out with our parents' class, job, and income. Being one of the few people not employed by the government, my father had never been officially classified. Since he was a medical doctor, he told me to put him down as an Intellectual. My homeroom teacher called 
me into the office a couple of days afterwards and told me that my father couldn't be an Intellectual if his income far exceeded that of a Capitalist. He also told me that since my father worked for Foreign Imperialists, my father should be classified as an Imperialist Lackey. The teacher looked nonplussed when I told him that my father couldn't be an Imperialist Lackey because he was a medical doctor. But I could tell from the way he took notes on my form that my father's job had put me in an unfavorable position in his eyes.

The Standard Chinese term "class" was not a new word for me. Since first grade, I had been taught sentences such as, "The Working class are the masters of New China." I had always known that it was good to be a worker, but until then, I had never felt threatened for not being one. That fall, "class" began to take on a new meaning for me. I noticed a group of Working-class students and teachers at school. I was made to understand that because of my class background, I was excluded from that group.

Another word that became important was "consciousness." One of the slogans posted in the school building read, "Turn our students into future Proletarians with socialist consciousness and education!" For several weeks we studied this slogan in our political philosophy course, a subject I had never had in elementary school. I still remember the definition of "socialist consciousness" that we were repeatedly tested on through the years: "Socialist consciousness is a person's political soul. It is the consciousness of the Proletarians represented by Marxist Mao Tse-tung thought. It takes expression in one's action, language, and lifestyle. It is the task of every Chinese student to grow up into a Proletarian with a socialist consciousness so that he can serve the people and the motherland." To make the abstract concept accessible to us, our teacher pointed out that the immediate task for students from Working-class families was to strengthen their socialist consciousnesses. For those of us who were from other class backgrounds, the task was to turn ourselves into Workers with socialist consciousnesses. The teacher never explained exactly how we were supposed to "turn" into Workers. Instead, we were given samples of the ritualistic annual plans we had to write at the beginning of each term. In these plans, we performed "self-criticism" on our consciousnesses and made vows to turn ourselves into Workers with socialist consciousnesses. The teacher's division between those who did and those who didn't have a socialist consciousness led me to reify the notion of "consciousness" into a thing one possesses. I equated this intangible "thing" with a concrete way of dressing, speaking, and writing. For instance, I never doubted that my political philosophy teacher had a socialist consciousness because she was from a steelworker's family (she announced this the first day of class) and was a Party member who wore grey cadre suits and talked like a philosophy textbook. I noticed other things about her. She had beautiful eyes and spoke Standard Chinese with such a pure accent that I thought she should be a film star. But I was embarrassed that I had noticed things that ought not to have been associated with her. I blamed my observation on my Bourgeois consciousness.

At the same time, the way reading and writing were taught through memorization and imitation also encouraged me to reduce concepts and ideas to simple 
definitions. In literature and political philosophy classes, we were taught a large number of quotations from Marx, Lenin, and Mao Tse-tung. Each concept that appeared in these quotations came with a definition. We were required to memorize the definitions of the words along with the quotations. Every time I memorized a definition, I felt I had learned a word: "The national red flag symbolizes the blood shed by Revolutionary ancestors for our socialist cause"; "New China rises like a red sun over the eastern horizon." As I memorized these sentences, I reduced their metaphors to dictionary meanings: "red" meant "Revolution" and "red sun" meant "New China" in the "language" of the Working class. I learned mechanically but eagerly. I soon became quite fluent in this new language.

As school began to define me as a political subject, my parents tried to build up my resistance to the "communist poisoning" by exposing me to the "great books"-novels by Charles Dickens, Nathaniel Hawthorne, Emily Brontë, Jane Austen, and writers from around the turn of the century. My parents implied that these writers represented how I, their child, should read and write. My parents replaced the word "Bourgeois" with the word "cultured." They reminded me that I was in school only to learn math and science. I needed to pass the other courses to stay in school, but I was not to let the "Red doctrines" corrupt my mind. Gone were the days when I could innocently write, "I saw the red, red rose among the green leaves," collapsing, as I did, English and Chinese cultural traditions. "Red" came to mean Revolution at school, "the Commies" at home, and adultery in The Scarlet Letter. Since I took these symbols and metaphors as meanings natural to people of the same class, I abandoned my earlier definitions of English and Standard Chinese as the language of home and the language of school. I now defined English as the language of the Bourgeois and Standard Chinese as the language of the Working class. I thought of the language of the Working class as someone else's language and the language of the Bourgeois as my language. But I also believed that, although the language of the Bourgeois was my real language, I could and would adopt the language of the Working class when I was at school. I began to put on and take off my Working class language in the same way I put on and took off my school clothes to avoid being criticized for wearing Bourgeois clothes.

In my literature classes, I learned the Working-class formula for reading. Each work in the textbook had a short "Author's Biography": "X X X , born in 19-- in the province of $X X$, is from a Worker's family. He joined the Revolution in 19--. He is a Revolutionary realist with a passionate love for the Party and Chinese Revolution. His work expresses the thoughts and emotions of the masses and sings praise to the prosperous socialist construction on all fronts of China." The teacher used the "Author's Biography" as a yardstick to measure the texts. We were taught to locate details in the texts that illustrated these summaries, such as words that expressed Workers' thoughts and emotions or events that illustrated the Workers' lives.

I learned a formula for Working-class writing in the composition classes. We were given sample essays and told to imitate them. The theme was always about how the collective taught the individual a lesson. I would write papers about 
labor-learning experiences or school-cleaning days, depending on the occasion of the collective activity closest to the assignment. To make each paper look different, I dressed it up with details about the date, the weather, the environment, or the appearance of the Master-worker who had taught me "the lesson." But as I became more and more fluent in the generic voice of the Working-class Student, I also became more and more self-conscious about the language we used at home.

For instance, in senior high we began to have English classes ("to study English for the Revolution," as the slogan on the cover of the textbook said), and I was given my first Chinese-English dictionary. There I discovered the English version of the term "class-struggle." (The Chinese characters for a school "class" and for a social "class" are different.) I had often used the English word "class" at home in sentences such as, "So and so has class," but I had not connected this sense of "class" with "class-struggle." Once the connection was made, I heard a second layer of meaning every time someone at home said a person had "class." The expression began to mean the person had the style and sophistication characteristic of the Bourgeoisie. The word lost its innocence. I was uneasy about hearing that second layer of meaning because I was sure my parents did not hear the word that way. I felt that therefore I should not be hearing it that way either. Hearing the second layer of meaning made me wonder if I was losing my English.

My suspicion deepened when I noticed myself unconsciously merging and switching between the "reading" of home and the "reading" of school. Once I had to write a report on The Revolutionary Family, a book about an illiterate woman's awakening and growth as a Revolutionary through the deaths of her husband and all her children for the cause of the Revolution. In one scene the woman deliberated over whether or not she should encourage her youngest son to join the Revolution. Her memory of her husband's death made her afraid to encourage her son. Yet she also remembered her earlier married life and the first time her husband tried to explain the meaning of the Revolution to her. These memories made her feel she should encourage her son to continue the cause his father had begun.

I was moved by this scene. "Moved" was a word my mother and sisters used a lot when we discussed books. Our favorite moments in novels were moments of what I would now call internal conflict, moments which we said "moved" us. I remember that we were "moved" by Jane Eyre when she was torn between her sense of ethics, which compelled her to leave the man she loved, and her impulse to stay with the only man who had ever loved her. We were also moved by Agnes in David Copperfield because of the way she restrained her love for David so that he could live happily with the woman he loved. My standard method of doing a book report was to model it on the review by the Publishing Bureau and to dress it up with detailed quotations from the book. The review of The Revolutionary Family emphasized the woman's Revolutionary spirit. I decided to use the scene that had moved me to illustrate this point. I wrote the report the night before it was due. When I had finished, I realized I couldn't possibly hand it in. 
Instead of illustrating her Revolutionary spirit, I had dwelled on her internal conflict, which could be seen as a moment of weak sentimentality that I should never have emphasized in a Revolutionary heroine. I wrote another report, taking care to illustrate the grandeur of her Revolutionary spirit by expanding on a quotation in which she decided that if the life of her son could change the lives of millions of sons, she should not begrudge his life for the cause of Revolution. I handed in my second version but kept the first in my desk.

I never showed it to anyone. I could never show it to people outside my family, because it had deviated so much from the reading enacted by the jacket review. Neither could I show it to my mother or sisters, because I was ashamed to have been so moved by such a "Revolutionary" book. My parents would have been shocked to learn that I could like such a book in the same way they liked Dickens. Writing this book report increased my fear that I was losing the command over both the "language of home" and the "language of school" that I had worked so hard to gain. I tried to remind myself that, if I could still tell when my reading or writing sounded incorrect, then I had retained my command over both languages. Yet I could no longer be confident of my command over either language because I had discovered that when I was not careful—or even when I was-my reading and writing often surprised me with its impurity. To prevent such impurity, I became very suspicious of my thoughts when I read or wrote. I was always asking myself why I was using this word, how I was using it, always afraid that I wasn't reading or writing correctly. What confused and frustrated me most was that I could not figure out why I was no longer able to read or write correctly without such painful deliberation.

I continued to read only because reading allowed me to keep my thoughts and confusion private. I hoped that somehow, if I watched myself carefully, I would figure out from the way I read whether I had really mastered the "languages." But writing became a dreadful chore. When I tried to keep a diary, I was so afraid that the voice of school might slip in that I could only list my daily activities. When I wrote for school, I worried that my Bourgeois sensibilities would betray me.

The more suspicious I became about the way I read and wrote, the more guilty I felt for losing the spontaneity with which I had learned to "use" these "languages." Writing the book report made me feel that my reading and writing in the "language" of either home or school could not be free of the interference of the other. But I was unable to acknowledge, grasp, or grapple with what I was experiencing, for both my parents and my teachers had suggested that, if I were a good student, such interference would and should not take place. I assumed that once I had "acquired" a discourse, I could simply switch it on and off every time I read and wrote as I would some electronic tool. Furthermore, I expected my readings and writings to come out in their correct forms whenever I switched the proper discourse on. I still regarded the discourse of home as natural and the discourse of school alien, but I never had doubted before that I could acquire both and switch them on and off according to the occasion. 
When my experience in writing conflicted with what I thought should happen when I used each discourse, I rejected my experience because it contradicted what my parents and teachers had taught me. I shied away from writing to avoid what I assumed I should not experience. But trying to avoid what should not happen did not keep it from recurring whenever I had to write. Eventually my confusion and frustration over these recurring experiences compelled me to search for an explanation: how and why had I failed to learn what my parents and teachers had worked so hard to teach me?

I now think of the internal scene for my reading and writing about The Revolutionary Family as a heated discussion between myself, the voices of home, and those of school. The review on the back of the book, the sample student papers I came across in my composition classes, my philosophy teacher-these I heard as voices of one group. My parents and my home readings were the voices of an opposing group. But the conversation between these opposing voices in the internal scene of my writing was not as polite and respectful as the parlor scene Kenneth Burke has portrayed (see epigraph). Rather, these voices struggled to dominate the discussion, constantly incorporating, dismissing, or suppressing the arguments of each other, like the battles between the hegemonic and counterhegemonic forces described in Raymond Williams' Marxism and Literature (108-14).

When I read The Revolutionary Family and wrote the first version of my report, I began with a quotation from the review. The voices of both home and school answered, clamoring to be heard. I tried to listen to one group and turn a deaf ear to the other. Both persisted. I negotiated my way through these conflicting voices, now agreeing with one, now agreeing with the other. I formed a reading out of my interaction with both. Yet I was afraid to have done so because both home and school had implied that I should speak in unison with only one of these groups and stand away from the discussion rather than participate in it.

My teachers and parents had persistently called my attention to the intensity of the discussion taking place on the external social scene. The story of my grandfather's failure and my father's success had from my early childhood made me aware of the conflict between Western and traditional Chinese cultures. My political education at school added another dimension to the conflict: the war of Marxist-Maoism against them both. Yet when my parents and teachers called my attention to the conflict, they stressed the anxiety of having to live through China's transformation from a semi-feudal, semi-capitalist, and semi-colonial society to a socialist one. Acquiring the discourse of the dominant group was, to them, a means of seeking alliance with that group and thus of surviving the whirlpool of cultural currents around them. As a result, they modeled their pedagogical practices on this utilitarian view of language. Being the eager student, I adopted this view of language as a tool for survival. It came to dominate my understanding of the discussion on the social and historical scene and to restrict my ability to participate in that discussion.

To begin with, the metaphor of language as a tool for survival led me to be passive in my use of discourse, to be a bystander in the discussion. In Burke's "parlor," everyone is involved in the discussion. As it goes on through history, 
what we call "communal discourses"-arguments specific to particular political, social, economic, ethnic, sexual, and family groups-form, re-form and transform. To use a discourse in such a scene is to participate in the argument and to contribute to the formation of the discourse. But when I was growing up, I could not take on the burden of such an active role in the discussion. For both home and school presented the existent conventions of the discourse each taught me as absolute laws for my action. They turned verbal action into a tool, a set of conventions produced and shaped prior to and outside of my own verbal acts. Because I saw language as a tool, I separated the process of producing the tool from the process of using it. The tool was made by someone else and was then acquired and used by me. How the others made it before I acquired it determined and guaranteed what it produced when I used it. I imagined that the more experienced and powerful members of the community were the ones responsible for making the tool. They were the ones who participated in the discussion and fought with opponents. When I used what they made, their labor and accomplishments would ensure the quality of my reading and writing. By using it, I could survive the heated discussion. When my immediate experience in writing the book report suggested that knowing the conventions of school did not guarantee the form and content of my report, when it suggested that I had to write the report with the work and responsibility I had assigned to those who wrote book reviews in the Publishing Bureau, I thought I had lost the tool I had earlier acquired.

Another reason I could not take up an active role in the argument was that my parents and teachers contrived to provide a scene free of conflict for practicing my various languages. It was as if their experience had made them aware of the conflict between their discourse and other discourses and of the struggle involved in reproducing the conventions of any discourse on a scene where more than one discourse exists. They seemed convinced that such conflict and struggle would overwhelm someone still learning the discourse. Home and school each contrived a purified space where only one discourse was spoken and heard. In their choice of textbooks, in the way they spoke, and in the way they required me to speak, each jealously silenced any voice that threatened to break the unison of the scene. The homogeneity of home and of school implied that only one discourse could and should be relevant in each place. It led me to believe I should leave behind, turn a deaf ear to, or forget the discourse of the other when I crossed the boundary dividing them. I expected myself to set down one discourse whenever I took up another just as I would take off or put on a particular set of clothes for school or home.

Despite my parents' and teachers' attempts to keep home and school discrete, the internal conflict between the two discourses continued whenever I read or wrote. Although I tried to suppress the voice of one discourse in the name of the other, having to speak aloud in the voice I had just silenced each time I crossed the boundary kept both voices active in my mind. Every "I think . .." from the voice of home or school brought forth a "However ..." or a "But . . ." from the voice of the opponents. To identify with the voice of home or school, I had to negotiate through the conflicting voices of both by restating, taking back, 
qualifying my thoughts. I was unconsciously doing so when I did my book report. But I could not use the interaction comfortably and constructively. Both my parents and my teachers had implied that my job was to prevent that interaction from happening. My sense of having failed to accomplish what they had taught silenced me.

To use the interaction between the discourses of home and school constructively, I would have to have seen reading or writing as a process in which I worked my way towards a stance through a dialectical process of identification and division. To identify with an ally, I would have to have grasped the distance between where he or she stood and where I was positioning myself. In taking a stance against an opponent, I would have to have grasped where my stance identified with the stance of my allies. Teetering along the "wavering line of pressure and counter-pressure" from both allies and opponents, I might have worked my way towards a stance of my own (Burke, A Rhetoric of Motives 23). Moreover, I would have to have understood that the voices in my mind, like the participants in the parlor scene, were in constant flux. As I came into contact with new and different groups of people or read different books, voices entered and left. Each time I read or wrote, the stance I negotiated out of these voices would always be at some distance from the stances I worked out in my previous and my later readings or writings.

I could not conceive such a form of action for myself because I saw reading and writing as an expression of an established stance. In delineating the conventions of a discourse, my parents and teachers had synthesized the stance they saw as typical for a representative member of the community. Burke calls this the stance of a "god" or the "prototype"; Williams calls it the "official" or "possible" stance of the community. Through the metaphor of the survival tool, my parents and teachers had led me to assume I could automatically reproduce the official stance of the discourse I used. Therefore, when I did my book report on The Revolutionary Family, I expected my knowledge of the official stance set by the book review to ensure the actual stance of my report. As it happened, I began by trying to take the official stance of the review. Other voices interrupted. I answered back. In the process, I worked out a stance approximate but not identical to the official stance I began with. Yet the experience of having to labor to realize my knowledge of the official stance or to prevent myself from wandering away from it frustrated and confused me. For even though I had been actually reading and writing in a Burkean scene, I was afraid to participate actively in the discussion. I assumed it was my role to survive by staying out of it.

Not long ago, my daughter told me that it bothered her to hear her friend "talk wrong." Having come to the United States from China with little English, my daughter has become sensitive to the way English, as spoken by her teachers, operates. As a result, she has amazed her teachers with her success in picking up the language and in adapting to life at school. Her concern to speak the English taught in the classroom "correctly" makes her uncomfortable when she hears people using "ain't" or double negatives, which her teacher considers "improper." I see in her the me that had eagerly learned and used the discourse 
of the Working class at school. Yet while I was torn between the two conflicting worlds of school and home, she moves with seeming ease from the conversations she hears over the dinner table to her teacher's words in the classroom. My husband and I are proud of the good work she does at school. We are glad she is spared the kinds of conflict between home and school I experienced at her age. Yet as we watch her becoming more and more fluent in the language of the classroom, we wonder if, by enabling her to "survive" school, her very fluency will silence her when the scene of her reading and writing expands beyond that of the composition classroom.

For when I listen to my daughter, to students, and to some composition teachers talking about the teaching and learning of writing, I am often alarmed by the degree to which the metaphor of a survival tool dominates their understanding of language as it once dominated my own. I am especially concerned with the way some composition classes focus on turning the classroom into a monological scene for the students' reading and writing. Most of our students live in a world similar to my daughter's, somewhere between the purified world of the classroom and the complex world of my adolescence. When composition classes encourage these students to ignore those voices that seem irrelevant to the purified world of the classroom, most students are often able to do so without much struggle. Some of them are so adept at doing it that the whole process has for them become automatic.

However, beyond the classroom and beyond the limited range of these students' immediate lives lies a much more complex and dynamic social and historical scene. To help these students become actors in such a scene, perhaps we need to call their attention to voices that may seem irrelevant to the discourse we teach rather than encourage them to shut them out. For example, we might intentionally complicate the classroom scene by bringing into it discourses that stand at varying distances from the one we teach. We might encourage students to explore ways of practicing the conventions of the discourse they are learning by negotiating through these conflicting voices. We could also encourage them to see themselves as responsible for forming or transforming as well as preserving the discourse they are learning.

As I think about what we might do to complicate the external and internal scenes of our students' writing, I hear my parents and teachers saying: "Not now. Keep them from the wrangle of the marketplace until they have acquired the discourse and are skilled at using it." And I answer: "Don't teach them to 'survive' the whirlpool of crosscurrents by avoiding it. Use the classroom to moderate the currents. Moderate the currents, but teach them from the beginning to struggle." When I think of the ways in which the teaching of reading and writing as classroom activities can frustrate the development of students, I am almost grateful for the overwhelming complexity of the circumstances in which I grew up. For it was this complexity that kept me from losing sight of the effort and choice involved in reading or writing with and through a discourse.

\section{Works Cited}

Burke, Kenneth. The Philosophy of Literary Form: Studies in Symbolic Action. 2nd ed. Baton Rouge: Louisiana State UP, 1967. 
. A Rhetoric of Motives. Berkeley: U of California P, 1969.

Freire, Paulo. Pedagogy of the Oppressed. Trans. M. B. Ramos. New York: Continuum, 1970.

Williams, Raymond. Marxism and Literature. New York: Oxford UP, 1977. 